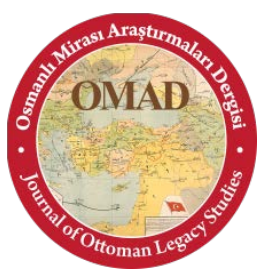

Osmanlı Mirası Araştırmaları Dergisi (OMAD), Cilt 5, Sayı 11, Mart 2018, ss.183-192.

Journal of Ottoman Legacy Studies (JOLS), Volume 5, Issue 11, March 2018, pp. 183-192.

ISSN 2148-5704

DOI Number: 10.17822/omad.2018.92

Geliş Tarihi/Received: 25.02.2018 Kabul Tarihi/Accepted: 24.03.2018

\title{
MONTENEGRO IN THE GEOPOLITICAL CONTEXT OF THE BALKANS
}

\author{
Miroslav DODEROVIĆ ${ }^{*}$, Marijan PREMOVIĆ ${ }^{* *}$
}

\begin{abstract}
The paper analyzes the position of Montenegro in three geopolitical concepts - Atlanticism, continentalism and Neo-Ottomanism. Atlanticism is traditionally interested in the control of the coastal area. In this context, for the US and the UK is much more convenient to have in that zone, in every respect weaker Montenegro, but militarily and economically strong state. From the point of principle interest Atlanticism, it can be concluded that the independence of Montenegro is the objective of this geopolitical concept. However, the Montenegrin coast represents the geopolitical contact zone of Atlanticism, Neo-Ottomanism and Continentalism. The most important geopolitical goal for Atlanticism in this part of the Mediterranean is the control of Otranto, and therefore the most interesting is the coastal zone of Albania. The second objective is to prevent the release of continentalism to the warm sea, which at first could happen in Istria and northern Dalmatia, and therefore the Croatian part of the Adriatic coast is of greater interest than the Montenegrin coast. Montenegro, regardless of its sea zone of great geopolitical interest to Atlanticism, has no primary importance for this geopolitical concept. That is why Atlanticism is likely and ready to transform geopolitical objectives in foreign policy doctrines and strategies and treat Montenegro just as an object of diplomatic trade. Immediately since the independence of Montenegro, Russia has been involved in a very original way in the geopolitical battle for the Adriatic.
\end{abstract}

Keywords: Geopolitics, Atlanticism, Neo-Ottomanism, continentalism

\section{Introduction}

Among the smallest European countries in the geographical and population terms Montenegro, located on the Balkans with its Mediterranean neighbours, currently belongs to one of the most dynamic and most promising regions. ${ }^{1}$ Here, the distinctive position and benefits deriving from it, Montenegro embeds the fundamental values of its foreign policy. By gaining independence for the first time in modern history, it is likely that it can significantly influence its own geopolitical and international position. Montenegro, due to its objective circumstances (the reality set by history), does not have the ability to decisively influence the development of a modern geopolitical order. Such constraints, which were set by the historical and geographical development of the Balkans (the economic lag behind Europe, the great suffering and displacement of the population, the fragmentation of the space in a large number of states founded mainly on the ethnic principle) influenced its territory and population.

The paper consists of segments which help to understand the position of Montenegro through its past and present: 1. Geographical context, 2. Geographical and historical context, 3.

\footnotetext{
* (Prof. Ph.D.); Faculty of Philosophy (Geography) at the University of Montenegro, e-mail: dodemir@t-com.me, ORCID: orcid.org/0000-0001-9720-8649

** (Prof. Ph.D.); Faculty of Philosophy (History) at the University of Montenegro, e-mail: premovicmarijan@yahoo.com, ORCID: orcid.org/0000-0001-6698-9462

${ }^{1}$ In the last two centuries, the Balkans has been one of the most explosive geopolitical nodes in the world. In addition to the countries that are geographically located on the Balkan Peninsula, the Balkan geopolitical nets in the wider sense also belong to Hungary, Romania, Moldova, Turkey, and even spatially distant Cyprus. Often, South East Europe is used for this region. See more: Mirko Grčić, Political Geography, Faculty of Geography, Belgrade 1999, p. 356 (hereinafter: Grčić, Political Geography).
} 
The position and role of Montenegro in the global geopolitical order, 4. Interes of three geopolitical conceptions - Atlanticism, continentalism and neo-Ottomanism and Montenegro in them.

\section{Geographic context}

In the new world geopolitical order, attention must be paid to the contemporary geopolitical position of Montenegro. The geopolitical position has more pronounced geographical factors as well as spatial and territorial component. When determining the geopolitical position, attention should be paid to the main factors determining it. These are geographical factors, global geopolitical structures, the political environment of Montenegro and the political situation in Montenegro itself. ${ }^{2}$ Each of these four basic factors is one that determines the geopolitical position of a territorial political unit, in this case of Montenegro. The first group of factors is geographic factors which comprise the geographical position of Montenegro, the position of large relief units in relation to Montenegro, the regional structure of Montenegro and the geo-traffic situation of Montenegro. Geographic factors have two basic characteristics, which are the basis for any further consideration of their development. These characteristics are omnipresence and de facto immutability.

Montenegro is located in the Balkans, ${ }^{3}$ and the coastal Montenegro i.e. Montenegrin coast is the part of the relief area of the Adriatic Sea. This heterogeneous relief structure of Montenegro has influenced its natural-geographical and economic features. Montenegro is a part of southern Europe (Montenegro participates in the coast $(300 \mathrm{~km})$ in the Adriatic Sea, which is a part of the Mediterranean Sea. It also belongs to southern Europe. It is the Mediterranean-Adriatic, Balkan country, located between $41^{\circ} 39$ 'and $43^{\circ} 32^{\prime}$ Northern geographic width and $18^{0} 26$ 'and $20^{\circ} 21^{\prime}$ ' east longitude ${ }^{4}$ bordered in the west by Croatia and Bosnia and Herzegovina, in the north by Serbia, in the northeast by Kosovo, in the southeast and east by Albania and in the southwest by the Adriatic Sea.

The principal comparative advantage of the position of Montenegro is its maritimeMediterranean position, which has marked its historical trends and cultural development. Another important feature of the geographical position of Montenegro is its connection to the wider hinterland of the Balkan Peninsula and the European main traffic corridors. The total length of its land borders is $614 \mathrm{~km}$, of which $14 \mathrm{~km}$ are borderline towards Croatia, $225 \mathrm{~km}$ towards Bosnia and Herzegovina, $124 \mathrm{~km}$ towards Serbia, 79km towards Kosovo and $172 \mathrm{~km}$ towards Albania, the state border (partly across Skadar Lake and along the Bojana River). The

\footnotetext{
${ }^{2}$ World power centers with geographical factors most significantly influence the formation of world geopolitical regions and their borders. The direct political environment and the internal political situation in Montenegro are not crucial for the position of Montenegro in the new world order if Montenegro achieves a consensus on the fundamental issues of foreign policy and action towards global geopolitical structures. Of course, this does not mean that the relationship with the neighbors should be neglected, because it must be the most important for Montenegro, along with the relationship with the European Union and NATO. The political situation in Montenegro can not permanently and fundamentally influence the position of Montenegro in the new world order, except in the case of some less likely events (the transformation of Montenegro into a rogue state due to the arrival of some extremists in power in Montenegro).

${ }^{3}$ The political geographical map of the Balkans scantily reflects all complex relationships and relationships. At the end of XX, 10 small and medium-sized countries were presented: the Republic of Bulgaria ( $\mathrm{P}=110000 \mathrm{~km} 2$ and 9 mil / inhabitants); Albania (P = $28000 \mathrm{~km} 2$ and $3.5 \mathrm{mil} / \mathrm{m} 2)$; Greece (131 $900 \mathrm{~km} 2$ and 10. mil / inhabitants). Turkey holds the eastern Thrace and Istanbul (P = $23000 \mathrm{~km} 2$ and $4.8 \mathrm{mil} / \mathrm{inh} .$.$) . Republic of Romania (\mathrm{P}=237$ $000 \mathrm{~km} 2$ and about $24 \mathrm{mil} /$ inhabitants). In the beginning of the 1990s, five countries were formed on the territory of the former SFRY ( $\mathrm{P}=255000 \mathrm{~km} 2$ and about 24 mil.), The Republic of Slovenia ( $\mathrm{P}=20000 \mathrm{~km} 2$ and 2 mil.), Croatia ( $\mathrm{P}=56000 \mathrm{~km} 2$ and $4.7 \mathrm{mil} / \mathrm{m} 2)$, Serbia and Montenegro ( $\mathrm{P}=102000 \mathrm{~km} 2$ and about $10.2 \mathrm{mil} /$ inhabitants) or Montenegro $13812 \mathrm{~km} 2$ and about 700000 inhabitants, Bosnia and Herzegovina consisting of the two entities - Srpska Republic (25 $000 \mathrm{~km} 2$ and $1.5 \mathrm{mil} /$ apartment) and the Muslim-Croat Federation $(\mathrm{P}=26084$ km2 and 3 mil / apartment) and Macedonia ( $\mathrm{P}=25000 \mathrm{~km} 2$ and 2 mil. ). Grčić, Political Geography, 1999, p. 450.

${ }^{4}$ Radovan Bakić, Position in space as a factor of development, Geographical Institute of the Faculty of Philosophy, Nikšić 2013, p. 33 (hereinafter: Bakić, Position in space).
} 
distance of the end points of the coast of Montenegro is $100 \mathrm{~km}$ of the airline, while the developed length of its coastline is $300.0 \mathrm{~km}$, which gives a coefficient of degradation of 3.00. Montenegro has a surface area and a population least of six republics in the former SFRY. It covers an area of $13,812 \mathrm{~km}^{2}$, or $5.4 \%$ of the territory of the former Yugoslavia. ${ }^{5}$ Comparative advantages arising from geographical and geo-traffic position are not the only advantages that Montenegro has. Other comparative advantages arising from geographical factors are heterogeneous relief structure, different types of climate, wealth of water and forest resources, very long and indented shoreline, wealth of plant and animal life.

\section{Geographical and historical context}

Today, Montenegro, or most of the Roman provinces of Prevails, was only called Diocletian by the end of the $10^{\text {th }}$ century. The name comes from the Roman city of Doclea which is located near Podgorica. The name Zeta, after the right tributary of the river Moraca, appears from the 11th century. The Turks penetrated the Balkan Peninsula in the 14th century. By the 18th century, when their withdrawal began, the Turks had made the majority in almost all the towns. In 1878 the Berlin Congress was held. It revised the provisions of the San Stefan Treaty, the conditions of peace that Russia had imposed on Turkey. At The Berlin Congress, Montenegro, Serbia, and Romania recognized independence. The Peace conference in Versailles in 1919 dealt with the redrawing of Europe's political map. ${ }^{6}$ The Austro-Hungary collapsed and disappeared from the political map of the world. The breakup of the AustroHungarian Empire created Czechoslovakia and Poland. The southern regions of the former Austro-Hungarian (Bosnia and Herzegovina, Slovenia, Dalmatia, Croatia, Vojvodina) entered together with Serbia and Montenegro as part of the Kingdom of SHS (Serbs, Croats and Slovenes) renamed in 1929 to the Kingdom of Yugoslavia. At the conference in Yalta in 1945, a bipolar world order was created and the division of interest spheres in the Balkans was made. ${ }^{7}$ The Constitution, adopted on April 27, 1992, proclaimed the FR Yugoslavia, a sovereign federal state, based on the equality of citizens and the equality of republics that are part of it. The third Yugoslavia was made up of republics of Serbia and Montenegro, in the territory of 102,179 km² and with 10,338,000 inhabitants (1990). ${ }^{8}$ FR Yugoslavia was the largest of the former SFRY countries. The founding of the new state was accompanied by economic problems from the previous period (production decline, critical unemployment, high inflation and deep structural disturbances, caused primarily by the non-market economy system and the long-standing unfavorable political situation in the country). An anomaly that was characteristic of the FRY should be highlighted. This was a great asymmetry in terms of the territory, and in terms of the size of the population between the two federal units, Montenegro and Serbia. Montenegro participated with $13.5 \%$ in the territory of FR Yugoslavia, with $6.1 \%$ in the total population, with $6.1 \%$ in terms of the number of employees and $4.9 \%$ in the social product. Montenegro renewed independence on May 21, 2006 in a referendum.

Foreign policy actions and moves by states can be explained within the framework of a geopolitical culture, which consists of geopolitical imaginations and geopolitical traditions, and affects everyday state practice. ${ }^{9}$ Montenegro, as a small country with a small population in a

\footnotetext{
${ }^{5}$ Bakić, Position in space, p. 34.

${ }^{6}$ Stevan K. Pavlovic, History of the Balkans 1804.-1945., Second edition, Klio, Belgrade 2004, p.67

${ }^{7}$ Radmila Nakarada, The Disintegration of Yugoslavia, Problems of Interpretation, Confrontation and Transition, Službeni glasnik, Beograd 2008, p. 276.

${ }^{8}$ Slavoljub B.Šušić, Geopolitical nightmare of the Balkans, VIZ, Belgrade 2004, p. 119.

${ }^{9}$ In the diplomatic system, the Balkan equilibrium was maintained by the formula $2+2+2$, which means: Greece + Turkey $=$ NATO Pact, Bulgaria + Romania $=$ Warsaw Pact, Yugoslavia + Albania $=$ Non-affiliation, or neutrality . With the collapse of the Warsaw Pact in 1991, the balance of power is disturbed. The new world order has marked a new schedule of economic impacts. New reengineering of particular egoisms. The collapse of SFR Yugoslavia in the Balkans creates three groups of states on cultural and civilizational basis.

1. Catholic (Slovenia + Croatia).

2. Islamic (Albania and part of $\mathrm{BiH}$, Kosovo).
} 
global scale, cannot influence changes in global geopolitical structures. However, global geopolitical structures and the most important actors of the global geopolitical order can significantly influence the international position of Montenegro with their direct or indirect, collateral action. Even in the gaining of independence and the confirmation of Montenegro by international recognition, international factors played a crucial role. ${ }^{10}$ Some of them were for the recognition of Montenegro, and most of the global geopolitical actors were against the recognition of new states, guided by the principle of the territorial integrity of the existing states. Montenegro, as a democratic and open country, in the new state capacity, develops political, economic and other relations with key countries in the world, with the intensity and importance of these relations to correspond with the national, national and overall interests of Montenegro. So far, 178 countries have recognized Montenegro and diplomatic relations have been established as well, and a considerable number of embassies have been opened in the capital of Podgorica, and the diplomatic and consular networks of Montenegro in the world are expanding.

\section{The position and role of Montenegro in the world's geopolitical order}

The position and role of Montenegro in the world geopolitical order will most significantly determine the attitude towards, and possible membership in European integrations (European Union and other integrations) and the Euro-Atlantic community (NATO alliance). This continental and Euro-Atlantic level is crucial for Montenegro, because it enables it to participate in joint decision-making, enter the large common market of the European Union and guarantee its national security and stability through participation in full NATO membership, as the strongest military-political alliance in the world. ${ }^{11}$ Montenegro, due to its political circumstances and international isolation in the second half of the 1990s, significantly lagged behind in the process of joining Europe and the Euro-Atlantic community.

By adopting the Declaration of Independence in the Parliament of the Republic of Montenegro on June 3, 2006, after the referendum on May 21, the Government of the Republic of Montenegro took over the responsibilities of establishing and conducting foreign policy, in the capacity of the state of Montenegro as an independent international legal entity. By changing the state status, Montenegro has not changed the direction of its foreign policy. On the contrary, the continuity of its foreign policy strivings makes the basic quality of the foreign policy position today. Accordingly, the Government has identified the following foreign policy priorities of Montenegro: Integration into the European Union and the North Atlantic Treaty Organization - NATO ${ }^{12}$, promoting and maintaining good neighborly relations and regional cooperation, developing bilateral and multilateral cooperation. Montenegro's foreign policy priorities are interlinked and complementary. Montenegro, through the establishment and realization of the basic priorities in relations with foreign countries, strives to integrate into European and Euro-Atlantic structures and all regional initiatives, monitors global trends and engages in them in accordance with interests and opportunities; develops good relations with neighbours; establishes and maintains good relations with a number of the most developed and largest countries in the world; while fully respecting the undertaken international obligations and principles. ${ }^{13}$ The fundamental foreign policy objectives of Montenegro are also linked in coordination with internal political and economic development. Montenegro's goals and interests can be expressed through the fundamental national interests identified in Montenegro in the following order: survival in peace and freedom and protection of independence, sovereignty and integrity, economic prosperity and well-being of all citizens, favorable

\footnotetext{
3. Orthodox countries that have not yet found a way to organize themselves.

${ }^{10}$ Blagoje Grahovac, Dangerous Things, Vijesti, Podgorica 2010, p. 59.

11 Adis Arapović, Foreign Policy of Bosnia and Herzegovina: Determinants and Perspectives, Tuzla Center for Civilian Perspectives, BiH, Faculty of Political Sciences, Sarajevo University, BiH, Sarajevo 2010, p. 103.

${ }^{12}$ Montenegro joined NATO on June 5th, 2017.

${ }^{13}$ Foreign Policy Priorities of Montenegro, http://www.mip.gov.me, February 15, 2011.
} 
environment and cooperation in the region, protection and promoting national values, and preserving resources. The protection of vital national interests is a fundamental prerequisite for the survival, existence, development and prosperity of each state, and so does Montenegro. Analyzing the geopolitical position of Montenegro, it is noted that it represents an area in which the diverse interests of Central Europe, Eurasia, the Atlantic and Islamic world are intertwined. ${ }^{14}$

\subsection{Integration into the European Union and the North Atlantic Treaty Organization - NATO}

Montenegro's strategic goal is membership in the European Union. This process will engulf Montenegro's foreign policy in the coming period, as the most important task on both the external and the internal plan. Montenegro sees the EU as the best framework for further development of overall reforms, adaptation to European standards and their adoption, as well as the improvement of bilateral relations with the members of the Union. In Montenegro, there is a comprehensive agreement on the need for EU integration, which gives an additional impulse for accelerated progress towards this goal. The speed of progress in integration will depend on the dynamics of economic, political, judicial, security and overall reforms, i.e. from the speed and degree in which society as a whole will be engaged and reformed.

Expectations are that entry into NATO will accelerate EU membership. By joining NATO and developing relations with this organization, it is expected that Montenegro will get the best security framework to prevent potential threats, challenges and risks to the stability of the state, the region and beyond, to promote its image of stable democracy, to accelerate economic development by attracting foreign investments and equally participate in the process of making relevant decisions. ${ }^{15}$ Montenegro's integration into NATO is closely linked to EU integration, because it is a two-way and compatible process. Democratic institutions, the rule of law, the market economy, a stable security situation are the fundamentals of every country that wants to become a member of the EU. Through NATO membership (which will necessarily have to constantly adjust to respond to new challenges), Montenegro will fully internationalize its security, improve its own national security system. The role and position of Montenegro in the geopolitical order of the near future will be more permanent and more determined. ${ }^{16}$

\subsection{Promotion and maintenance of good cooperative relations and regional cooperation}

Montenegro's strategic integrative goals - EU accession - cannot be achieved without the active role of Montenegro in regional cooperation, developing good neighborly relations in the regional context. ${ }^{17}$ Although it borders Albania, Bosnia and Herzegovina, Kosovo, Italy, Serbia and Croatia, Montenegro in the neighboring countries for historical and political reasons, in the regional context, includes the Former Yugoslav republic of Macedonia and Slovenia, as well as the neighbours of the former Yugoslavia Austria, Hungary, Romania, Bulgaria and Greece. The goal is to develop good relations and communication with mutual respect and continuous building of political, economic, security, cultural, scientific contacts and cooperation, and extremely important infra-structural connectivity. In this context, relations with Serbia are of particular importance with all these countries. Montenegro does not only share the same geographical area, but also the same foreign policy objectives with these countries. Foreign policy priorities are conditioned by joint work and cooperation with other countries of the region. In this context, the progress of each country in the region means an incentive for the

\footnotetext{
${ }_{14}^{14}$ Alexander Dugin, Fundamentals of Geopolitics - Russia's Geopolitical Future, Ekopres, Zrenjanin, 2004, p. 43.

${ }^{15} \mathrm{http} / / / w w w . m i p . g o v . m e, 15.2 .2011$.

${ }^{16}$ Ibidem.

${ }^{17}$ Radmila Nakarada, Disintegration of Yugoslavia, problems of interpretation, confrontation and transition, Official Gazette, Belgrade 2008, p. 276.
} 
progress of Montenegro. Montenegro supports the development of regional cooperation and further improvement of cooperation mechanisms among the countries of South-Eastern Europe. In this way, we strengthen individual relations with the countries of the region and help our region and its progress in European and Euro-Atlantic integrations. Montenegro is a credible partner in all regional organizations and initiatives (SEECP, CEI, JJI, SECI, SEDM, A3 + 3, etc.) and will look for full membership in the associations in which it is now an observer. Montenegro's security is now largely internationalized, but still significantly depends on the opportunities in Southeast Europe, i.e. in an unstable part of the political environment of Montenegro. The military danger in southeast Europe today is not great, but despite the presence of international troops (Kosovo and Bosnia and Herzegovina), there are still threats of outbreaks and low-intensity conflicts, which undermine the stability of neighboring countries, and even Montenegro. The unfinished processes of democratization and economic transformation in transitional countries, illegal migration, migration of residents caused by war conflicts, human and drug trafficking, organized crime, terrorism are emerging as potential sources of threat. It is specifically the south-east of Europe hit by these threats. ${ }^{18}$

\subsection{Developing bilateral and multilateral international cooperation}

Generally speaking, open questions arising from the breakup of the SFRY can be grouped into several main areas. The first segment consists of territorial issues, the second of national minority issues, and third of economic issues. Territorial issues were initially aimed at redefining borders on the territory of the former SFRY according to ethnic principles. By accepting the conclusions of the Badinter Commission, the status quo of the former republics borders began to stabilize in terms of territorial pretensions, but new issues and problems arise in attempting to define borderlines. The delineation at sea in the former Yugoslavia did not exist, while the land division relied on the jurisdiction of the municipalities, not the republics. Thus, Croatia had a maritime demarcation with as many as three countries of the former SFR Yugoslavia: Slovenia, Bosnia and Herzegovina and Montenegro. ${ }^{19}$ Montenegro has ratified the border with Kosovo, Bosnia and Herzegovina, Serbia and Albania. The border with Croatia (the Prevlaka peninsula issue), has not been ratified yet. When attempting to demarcate land borders, disproportions of the situation on the ground have been identified from the belief "where the border should go" and the disagreements of the parties to the dispute over these facts. ${ }^{20}$

The second question arising from the breakup of Yugoslavia is the question of the protection and recognition of newly born minorities. The SFRY was one of the most heterogeneous states in Europe and had so called three-layer system of national law. The first layer involved the peoples of Yugoslavia, each of which had its "base" in one of the republics. The second layer consisted of the nationalities of Yugoslavia, which were guaranteed a multitude of cultural rights. ${ }^{21}$ Except in the last Constitution of the SFRY of 1974, the notion of nationality was incorporated into the constitutions of all republics and provinces, with these constitutions (except in the case of Bosnia and Herzegovina and Montenegro) also constituting a category of ethnic groups. A category of other nationalities and ethnic groups was the third layer of a three-tier system of national law. The dissolution of Yugoslavia, until then the constituent peoples, in the territory of republics in which they were not dominant, became national minorities. The process of recognizing their status in some countries lasts even today.

The specificity of the two most sensitive foreign policy issues - the border and the minority - in the case of the countries formed by the breakup of the SFRY, stems from the very

\footnotetext{
${ }^{18}$ http://www.mip.gov.me, 15. 2. 2011.

${ }^{19}$ Jovan Bazić, Serbian issue - political concepts of solving the Serbian national question, Public Enterprise Official Gazette, Belgrade 2003, p. 230.

${ }^{20}$ Zoran Petrović Piroćanac, The Little Glimpse of Geopolitics, Institute for Political Studies, Belgrade, 2004, p. 146.

${ }^{21}$ The status of "nationality" had ten ethnic groups: Albanians (the most numerous), Hungarians, Bulgarians, Czechs, Roma, Italians, Romanians, Rusyns, Slovaks and Turks.
} 
collapse of that state community. The dissolution of the SFRY in the territory of the former republics created new national minorities. At the same time, there were three times more new state borders than the total length of the borders of the SFRY. In either case, these are not new borders or changes in the composition of the population, but the existing border lines and the population have a different status. ${ }^{22}$

The last group of issues is economic, succession of property, debt and archives at the state level and property law relations. The issue of the succession of the former Yugoslavia is broader than the bilateral framework and includes according to the original contract five, after the dissolution of Serbia and Montenegro, six countries of the former Yugoslavia. Property law is a matter that is dealt with in the context of individual requests and cases within Annex G of the said Treaty on the issues of succession of the former Yugoslavia. Although property issues appear partly as obstacles in relations, primarily in the media, there are no official positions in which it would be highlighted as problematic issues or obstacles in the relations between the countries of the environment and Montenegro. (Montenegro's foreign policy priorities) ${ }^{23}$ Note that the modern Balkans, as a region in the sign of "lumpen development or sub-development, as a zone of new dependent societies of semi-superpower capitalism, with devastated economies and weaker countries with compreated bourgeoisie and satellite elites." ${ }^{24}$

Strengthening relations and cooperation with the influential countries of the EU, Germany, Great Britain, France and Italy, key partners in international organizations and the international political scene, is an important factor for achieving Montenegro's foreign policy goals, as well as for its internal development. The overall cooperation with these countries through permanent bilateral contacts, but also through the processes of European and EuroAtlantic integration, will contribute to the economic and democratic progress of Montenegro and help the dynamics of our integration. In addition to the mentioned countries, Montenegro nourishes special, more quality and more pronounced relations with other countries in Europe. Hungary, as a Central European country with a good traffic position in the Pannonian Plain, should be the road to Central and Eastern Europe. Montenegro as a country, unlike Hungary, participates in the world's sea. Hungary is an important trading partner of Montenegro. Hungary has been since 1999 a member of NATO and a member of the European Union and also a member of CEFTA. Continuation of cooperation and development of intensive relations in all fields should be a policy towards Hungary. Particular emphasis is placed on improving relations with the countries of Central Europe (Poland, Czech Republic, and Slovakia) and the Baltic and Scandinavian countries. With small European countries (Iceland, Cyprus, Malta, Andorra, Luxembourg, Liechtenstein, Monaco and San Marino), Montenegro develops special relationships based on the exchange of experiences on the success of small and flexible administrations. It is noted that the main problem is the long-term decline in European economic power in relation to East Asia and America, and this problem is not solved, politicians are too busy solving urgent problems, so they do not have time for essential ones. ${ }^{25}$

\section{The interests of three geopolitical conceptions - Atlanticism, continentalism and neo-ottomanism, and Montenegro as the part}

The Montenegrin coast represents the geopolitical contact zone of Atlanticism, neoottomanism, continentalism and the permanent geopolitical interests of Catholicism. The most important geopolitical goal for Atlanticism in this part of the Mediterranean is the control of Otranto, which is why the Albanian part of the coast is the most interesting. The second goal is

\footnotetext{
${ }^{22}$ Grčić, Political Geography, 1999, p. 356.

${ }^{23}$ http://www.mip.gov.me, 15. 2. 2011.

${ }^{24}$ Ljubiša Mitrović, Position of the Balkans in Contemporary Geostrategic Examinations, group of authors, Serbia and contemporary processes in Europe and the world, Faculty of Geography, Belgrade 2005, p. 167.

${ }^{25}$ Radovan Vukadinović, "NATO's action in Yugoslavia and the new world order", The Political Thought, vol. XXXVI/2,Yale 1999, p. 15-24.
} 
to prevent continentalism from entering the warm sea, which can happen first in Istria or in northern Dalmatia, which is why the Croatian part of the Adriatic coast is also more interesting than the Montenegrin Riviera. Montenegro, regardless of the fact that it has a sea access to a zone of great geopolitical interest of Atlanticism, has no primary importance for this geopolitical conception. Because of this, Atlanticism is probably ready to convert the geopolitical goals into foreign policy doctrines and strategies in terms of Montenegro or treat it as an object of diplomatic trade. Montenegro will gain first-rate significance for Atlanticism only if there is a strategic partnership between continentalism and neo-ottomanism, or if continentalism sufficiently strengthens to bring Croatia and Albania into its orbit of control (there are historical examples that show this scenario possible). Continentalism, in particular its "Austrian electricity", shows the interest in establishing the influence in Montenegro in a long historical continuity. It is also linked to attempts to break into the warm sea, but also to reduce the impact of Serbia. In the end, for the neo-ottomanism, the northern part of Montenegro is crucial. It is a place that inhabits the Muslim population in large numbers and represents a geographical bridge between the territory of northern Kosovo and eastern Bosnia. For neoottomanism, the northern part of Montenegro is an important link in the formation of a "green transversal". ${ }^{26}$

With coordinated, planned action towards all entities of international relations operating in the international community, Montenegro can and should adapt to new challenges. Challenges are the further development of the new world order, in which there are processes of globalization, deterritorialization, new threats to national security that cannot be territorially restricted and retained today (the containment strategy cannot today be an effective response to global challenges to national security). Foreign policy priorities and values are fully dedicated to the faster development and overall prosperity of Montenegrin society. The speed and success of each stage on this path towards the ultimate destination are directly dependent on political determination, the continued and patient upgrading of all available capacities and institutions, as well as the mobilization of all resources to achieve the objectives of a broad social consensus, as well as where that relationship should be provided. Building and improving Montenegro as a modern, European country that belongs to the Balkan and Mediterranean civilization circle, shares completely European values and goals and is committed to respecting all international obligations undertaken, respecting human rights and developing a sustainable economy - is also a guarantor of the success of its foreign policy activities and the backbone of its establishment towards the international community and the regional environment.

\section{Conclusion}

Montenegro is Adriatic-Mediterranean Dinaric country of Southeast Europe, located between $41^{\circ} 39^{\prime}$ and $43^{0} 32^{\prime}$ North latitude and $18^{\circ} 26^{\prime}$ and $20^{\circ} 21^{\prime}$ eastern longitude. The border on the west side is with the Croatia and Bosnia and Herzegovina, from the north and north-east with Serbia, from the southeast and east with Albania and in the southwest to the Adriatic Sea. The greatest comparative advantage position of Montenegro is its Mediterranean position which has marked its historic and cultural development. Another important feature of the geographical position of Montenegro is its relationship with the wider hinterland of the Balkan Peninsula and the main European transport corridors. Namely, Montenegro is in its position by the side of the hinterland of the Balkan Peninsula, because it is not located directly on the main routes of European corridors (I-X). The paper analyzes the position of Montenegro in three geopolitical concepts - Atlanticism, continentalism and Neo-Ottomanism. Atlanticism is traditionally interested in the control of the coast and in the context of the US and the UK much more suited to this zone to have in every respect weaker Montenegro, but militarily and economically stronger state. Seen from the point of view of principle interest of Atlanticism, it can be

\footnotetext{
${ }^{26}$ Darko Tanasković, Neo Ottomanism, Doctrine and Foreign Political Practice, Službeni glasnik, Belgrade 2009, p. 93.
} 
concluded that the independence of Montenegro was the objective of this geopolitical concept. However, the Montenegrin coast represents the contact zone of geopolitical Atlanticism, NeoOttomanism and continentalism. The most important geopolitical goal for Atlanticism in this part of the Mediterranean is the control of Otranto, and therefore the most interesting part of the coast of Albania. The second objective is to prevent the release of continentalism to the warm sea, which at first can happen in Istria and northern Dalmatia, and therefore the Croatian part of the Adriatic coast is more interesting than the Montenegrin coast. Montenegro, regardless the sea being in a zone of great geopolitical interest of Atlanticism, has no primary importance for this geopolitical concept. Defined foreign policy priorities of Montenegro are long-term and reflect the needs and interests of Montenegro, especially in the political and developmental terms. Also, they reflect realistic possibilities and projections of Montenegro in light of its independence, as an independent and internationally recognized state and a long-term strategic positioning in the international arena. However, the success of Montenegro in foreign policy will depend primarily and mainly on the speed and quality of internal reforms and economic development. Coordinated, planned actions to all subjects of international relations that operate in the international community, Montenegro can and should be adapted to the new challenges. The challenges are the further development of the new world order, in which there are processes of globalization, deterritorialization, new threats to national security, which today cannot be territorially limited and retained (containment strategy today may not be an effective response to global challenges to national security).

\section{Bibliography}

Arapović, Adis, Foreign Policy of Bosnia and Herzegovina: Determinants and Perspectives, Tuzla Center for Civilian Perspectives, BiH, Faculty of Political Sciences, Sarajevo University, BiH, Sarajevo 2010.

Bakić, Radovan, Position in space as a factor of development, Geographical Institute of the Faculty of Philosophy, Nikšić 2013.

Bazić, Jovan, Serbian issue - political concepts of solving the Serbian national question, Public Enterprise Official Gazette, Belgrade 2003.

Dugin, Alexander, Fundamentals of Geopolitics - Russia's Geopolitical Future, Ekopres, Zrenjanin, 2004.

Grahovac, Blagoje, Dangerous Things, Vijesti, Podgorica 2010.

Grčić, Mirko, Political Geography, Faculty of Geography, Belgrade 1999.

Mitrović, Ljubiša, Position of the Balkans in Contemporary Geostrategic Examinations, group of authors, Serbia and contemporary processes in Europe and the world, Faculty of Geography, Belgrade 2005.

Nakarada, Radmila, Disintegration of Yugoslavia, problems of interpretation, confrontation and transition, Official Gazette, Belgrade 2008.

Nakarada, Radmila, The Disintegration of Yugoslavia, Problems of Interpretation, Confrontation and Transition, Službeni glasnik, Beograd 2008.

Pavlovic, K. Stevan, History of the Balkans 1804.-1945., Second edition, Klio, Belgrade 2004.

Piroćanac Petrović, Zoran, The Little Glimpse of Geopolitics, Institute for Political Studies, Belgrade 2004.

Šušić, B. Slavoljub, Geopolitical nightmare of the Balkans, VIZ, Belgrade 2004. 
Tanasković, Darko, Neo Ottomanism, Doctrine and Foreign Political Practice, Službeni glasnik, Belgrade 2009.

Vukadinović, Radovan, "NATO's action in Yugoslavia and the new world order”, The Political Thought, vol. XXXVI/2, Yale 1999, p. 15-24

\section{Web source}

http://www.mip.gov.me, February 15, 2011. 